\title{
Changes of PGFM and Sex Steroid Hormones in Blood of Horses Pre-, During and Post-Parturition
}

\author{
Kaoru TAKAGI, Toshitada HIGASHINO, \\ Shigehisa TSUMAGARI, Shigeo OHBA, \\ Shinichi NAMBA, Kazumasa MORIKI, \\ Shosuke SATOH and Masatoshi TAKEISHI
}

Department of Veterinary Medicine, College

of Agriculture and Veterinary Medicine, Nihon

University, Fujisawa, Kanagawa 252, Japan

\begin{abstract}
Investigations on the pre-parturition, immediately after (during) parturition and postparturition blood levels of 13, 14-dihydro-15-keto-PGF $2 \alpha$ (PGFM) and sex-steroid hormones of 5 thoroughbred mares were carried out for a period of 12 months (May, 1984-April, 1985). PGFM and hormonal levels were determined with radioimmunoassays. PGFM and cortisol concentrations on pre-parturition day (prePD) 1 and 0 were much higher than on prePD 2, and returned to pre-parturition basal values on following parturition, respectively. Progesterone, estrone and estradiol- $17 \beta$ gradually decreased from prePD 7 to parturition day. Estradiol-17 $\beta$ was consistently low compared with estrone. In view of the above findings, $\mathrm{PGF}_{2} \alpha$ probably influences parturition in pregnant mares.
\end{abstract}

Key words: Parturition, PGFM, Steroid hormone, pregnant mares.

(J. Reprod. Dev. 38: 23-28, 1992)

C ontroversial and different theories such as the estrogen-progesterone theory, prostaglandin theory, oxytocin theory and embryonic cortisol theory are recent thoughts that focus on the phenomenon that involves endogenous hormonal secretions in triggering parturition. In equine research, the progesterone concentration in the blood of breeders from term-pregnancy to parturition and suckling is $4.4 \pm 1.1 \mathrm{ng} / \mathrm{ml}$ on preparturition day (prePD) 5 , and decreases to 0.5 $\mathrm{ng} / \mathrm{ml}$ on prePD 1-3 [1]. Moreover, estrogen and progesterone in the peripheral blood of hybrid horses manifest a marked decrease $48 \mathrm{~h}$ before parturition [2]. Further, when the prostaglandin F2 $\alpha\left(\mathrm{PGF}_{2} \alpha\right)$ content in uterine venous blood was determined, a sharp increase was seen during parturition. However, such a finding in thoroughbred mares has yet to be reported [3].

Accepted for Publication: July 30, 1991

Correspondence: K. Takagi
This study was carried out to investigate the changes of 13, 14-dihydro-15-keto-PGF $2 \alpha$ (PGFM) and sex-steroid hormonal levels in peripheral blood of Thoroughbred mares pre-parturition, immediately after (during) purturition and postparturition. Hormonal levels were determined with radioimmunoassays.

\section{Materials and Methods}

\section{Horses}

Five thoroughbred mares, aged 6-10 years, from 2 race stables in Japan (Hokkaido) were used for the experiments.

\section{Blood sampling}

Monthly collections (between 08:00-09:00 h) of blood for a period of 14 days (prePD $7 \sim$ 
post-parturition days (postPD) 6) from 5 pregnant horses were carried out. To study the changes in hormonal levels in relation parturition, samples of blood from the jugular vein were taken from 5 pregnant horses throughout prePD 3 to 7 , during parturition and postPD 3 to 6 . The blood samples were subjected to centrifugation $(3,000 \mathrm{rpm}, 10$ min), and the supernatant was then placed in polyethylene containers and stored at $-20 \mathrm{C}$ until the assay.

\section{Data recording}

The last day of mating was termed as day 0 , and the next day was considered as pregnancy day (PD) 1. In the case of a parturition horse, prePD 1 was read as -1 , parturition day as day 0 and the following days were $+1,+2$ and so on.

Estrone, estradiol-17 $\beta$ and cortisol determinations: Plasma estrone, estradiol- $17 \beta$ and cortisol levels were determined with the RIA described by Makino [4]. Plasma was extracted with ethyl ether and the dried extract was subjected to Sephadex LH-20 chromatography for estrone and estradiol$17 \beta$, and cortisol determinations. Antisera to estrone-6-CMO-BSA, estradiol-17 $\beta$-6-CMO-BSA and F-21-succ-BSA were purchased from the Teikoku Hormone Manufacturing Co. (Tokyo, Japan). The cross-reactivity values for estrone antisera against estradiol- $17 \beta$ and estriol were $2 \%$ and $1.6 \%$, respectively; those of estradiol- $17 \beta$ antisera to estrone and estriol were $3 \%$ and $2 \%$, respectively. In the case of cortisol antisera, the respective values were $92.3 \%$ and $28.1 \%$ for $17 \alpha$-OHP and cortisone respectively. The coefficients of variation for intra- and inter-assay were $11.2 \%$ and $17.4 \%$ for estrone; $15.7 \%$ and $19.6 \%$ for estradiol- $17 \beta ; 8.1 \%$ and $11.9 \%$ for cortisol, respectively.

Progesterone determination: Assays on these hormones were performed with the RIA described by Den et al. [5]. The antiserum to Progesterone-3CMO-BSA was purchased from the Teikoku Hormone Manufacturing Co. (Tokyo, Japan). Crossreactivity values for $5 \alpha$-pregnanedione and $20 \alpha$ $\mathrm{OH}$ progesterone (20 $\alpha$-OHP) were $42.6 \%$ and $7 \%$, respectively. Those of $17 \alpha-\mathrm{OH}$ progesterone $(17 \alpha-$ OHP) antisera against progesterone and $20 \alpha$-OHP were $7.9 \%$ and $3.2 \%$, respectively. However, those of $20 \alpha$-OHP antisera against $20 \beta$-OHP and progesterone were $5.4 \%$ and $2.9 \%$, respectively. The coefficients of variation for intra- and inter-assay were $8.7 \%$ and $12.6 \%$ for progesterone; $11.1 \%$ and $15.7 \%$ for $17 \alpha-\mathrm{OHP} ; 10.2 \%$ and $14.5 \%$ for $20 \alpha$-OHP, respectively.

PGFM determination: PGFM was determined with the RIA described by Satoh et al. [6]. The Antiserum against PGFM-BSA was purchased from Institute Pasteur Production (Coquette, French). Cross-reactions with 13, 14-dihydro, 15keto-PGF $\alpha$, and 15 -keto-PGF 2 , were $83 \%, 23 \%$ and $4.4 \%$, respectively. The intra- and inter-assay coefficients of variation were $13.8 \%$ and $17.4 \%$, respectively.

\section{Results}

Changes in the hormone concentrations in the blood of horse No. 1: Estrone concentrations were $0.79-0.98 \mathrm{ng} / \mathrm{ml}$ on prePD $7-2$, decreased to 0.48 $\mathrm{ng} / \mathrm{ml}$ on prePD 1 , and then maintained at $0.34-0.52 \mathrm{ng} / \mathrm{ml}$ thereafter. Estradiol- $17 \beta$ concentrations were approximately $0.18 \mathrm{ng} / \mathrm{ml}$ during pre-parturition and dropped lower postparturition. Progesterone was high at $45 \mathrm{ng} / \mathrm{ml}$ on prePD 7-2, decreased to $26.8 \mathrm{ng} / \mathrm{ml}$ on parturition, and dropped steeply to $3.3 \mathrm{ng} / \mathrm{ml}$ on postPD 1. Cortisol was about $50 \mathrm{ng} / \mathrm{ml}$ on prePD 2, increased to $88.5 \mathrm{ng} / \mathrm{ml}$ during parturition but decreased to $29.0 \mathrm{ng} / \mathrm{ml}$ post-parturition. PGFM reached a low level of $0.48 \mathrm{ng} / \mathrm{ml}$ till prePD 2, and then increased sharply from prePD 1 to register a peak value of $20.37 \mathrm{ng} / \mathrm{ml}$ on parturition (Fig. 1).

Changes in the hormone concentrations in the blood of horse No. 2: Estrone declined gradually from $0.82 \mathrm{ng} / \mathrm{ml}$ on prePD 4 to $0.42 \mathrm{ng} / \mathrm{ml}$ on prePD 2. Similarly, estradiol- $17 \beta$ was maintained at $0.11 \mathrm{ng} / \mathrm{ml}$ and declined to $0.04 \mathrm{ng} / \mathrm{ml}$ near parturition. Progesterone was more than $40 \mathrm{ng} / \mathrm{ml}$ till prePD 1, but declined to less than $21 \mathrm{ng} / \mathrm{ml}$ on parturition. Cortisol reached $55 \mathrm{ng} / \mathrm{ml}$ on prePD 1, peaked with a value of $121.0 \mathrm{ng} / \mathrm{ml}$ on parturition, only to decrease below the pre-parturition level the next day. PGFM increased sharply on prePD 1, peaked at $15.25 \mathrm{ng} / \mathrm{ml}$ parturition and declined abruptly on post-parturition (Fig. 2).

Changes in the hormone concentrations in the blood of horse No. 3: Estrone was at a low of 0.49 $\mathrm{ng} / \mathrm{ml}$ when first determined, followed by a further decrease thereafter. Estradiol-17 $\beta$ varied around $0.06 \mathrm{ng} / \mathrm{ml}$. Similarly to estrone, progesterone was low in initial determinations, decreased from $19.8 \mathrm{ng} / \mathrm{ml}$ on parturition to $4.5 \mathrm{ng} / \mathrm{ml}$ on 


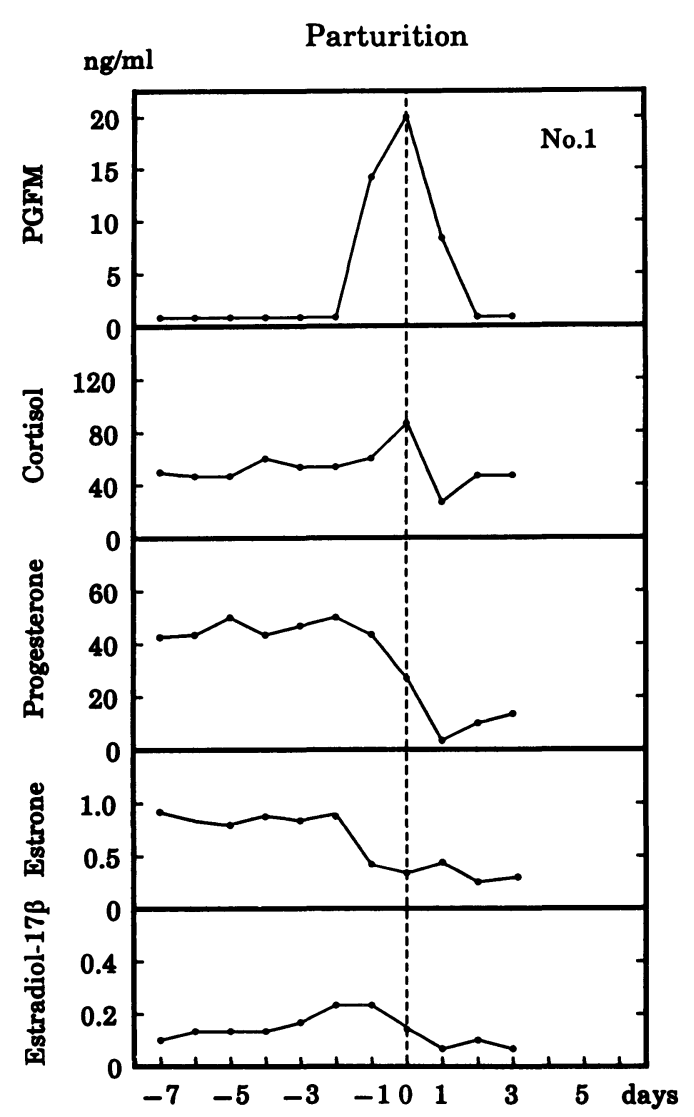

Fig. 1. Changes of PGFM, Cortisol, Progesterone, Estrone and Estradiol-17 $\beta$ in blood of horse No. 1 pre- during and postparturition.

postPD 1. Cortisol, after reaching the peak level of $120.7 \mathrm{ng} / \mathrm{ml}$ on parturition, decreased to 43.4 $\mathrm{ng} / \mathrm{ml}$ on postPD 3. PGFM maintained a high level of $12.90 \mathrm{ng} / \mathrm{ml}$ on parturition only to decline to $0.05 \mathrm{ng} / \mathrm{ml}$ on postPD 2 (Fig. 3).

Changes in the hormonal concentrations in the blood of horse No. 4: Estrone decreased from 0.39 $\mathrm{ng} / \mathrm{ml}$ on prePD 4 to $0.21 \mathrm{ng} / \mathrm{ml}$ post-parturition. Estradiol- $17 \beta$ hardly changed around $0.15 \mathrm{ng} / \mathrm{ml}$. Progesterone registered a pre-parturition level of $38.8 \mathrm{ng} / \mathrm{ml}$, decreased to $18.9 \mathrm{ng} / \mathrm{ml}$ on parturition and dropped further to $3.7 \mathrm{ng} / \mathrm{ml}$ on postPD 1 . Cortisol peaked at $128.9 \mathrm{ng} / \mathrm{ml}$ on parturition from a pre-parturition level of $59.7 \mathrm{ng} / \mathrm{ml}$ and decreased to $36.0 \mathrm{ng} / \mathrm{ml}$ on postPD 6 . PGFM was low on prePD 4 , increased sharply on prePD 1 , peaked at $18.21 \mathrm{ng} / \mathrm{ml}$ on parturition but decreased to $3.98 \mathrm{ng} / \mathrm{ml}$ on postPD 1 . The concentrations decreased further to $0.46 \mathrm{ng} / \mathrm{ml}$ on postparturition. (Fig. 4).

Changes in the hormonal concentrations in the

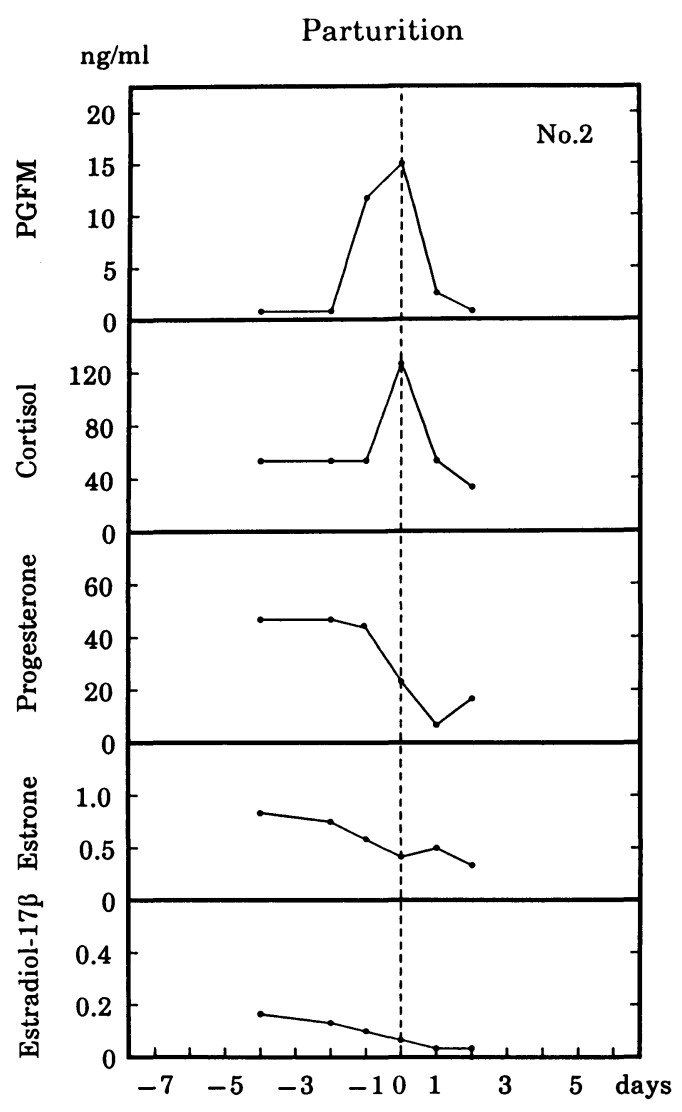

Fig. 2. Changes of PGFM, Cortisol, Progesterone, Estrone and Estradiol-17 $\beta$ in blood of horse No. 2 pre- during and postparturition.

blood of horse No. 5: Estrone levels registered $0.42 \mathrm{ng} / \mathrm{ml}$ on pre-parturition and lowered to $0.05-0.27 \mathrm{ng} / \mathrm{ml}$ on parturition. Estradiol-17 $\beta$ levels approximated to $0.13 \mathrm{ng} / \mathrm{ml}$ on parturition, and declined to a low value of about $0.03 \mathrm{ng} / \mathrm{ml}$ on post-parturition. Progesterone registered a preparturition level of $45 \mathrm{ng} / \mathrm{ml}$, decreased to 16.5 $\mathrm{ng} / \mathrm{ml}$ on parturition and varied around $1-9 \mathrm{ng} / \mathrm{ml}$ on postPD1. Cortisol levels increased to $83.8 \mathrm{ng} / \mathrm{ml}$ from $55 \mathrm{ng} / \mathrm{ml}$ on prePD 1 , peaked at $116.8 \mathrm{ng} / \mathrm{ml}$ on parturition but only to decrease to $42.2 \mathrm{ng} / \mathrm{ml}$ on postPD 1. PGFM increased sharply on prePD 2 to peak at $9.11 \mathrm{ng} / \mathrm{ml}$ on parturition, the level declined sharply on postPD 1 (Fig. 5).

The blood PGFM concentrations in the 5 thoroughbred mares were low until a few days prior to parturition. However, this PGFM concentrations increased from prePD 1 to peak at $15.17 \pm 4.42$ $\mathrm{ng} / \mathrm{ml}$ on parturition. PGFM decreased gradually after parturition, and recovered to its preparturition level of $0.06 \pm 0.02$ on postPD 2 (Fig. 


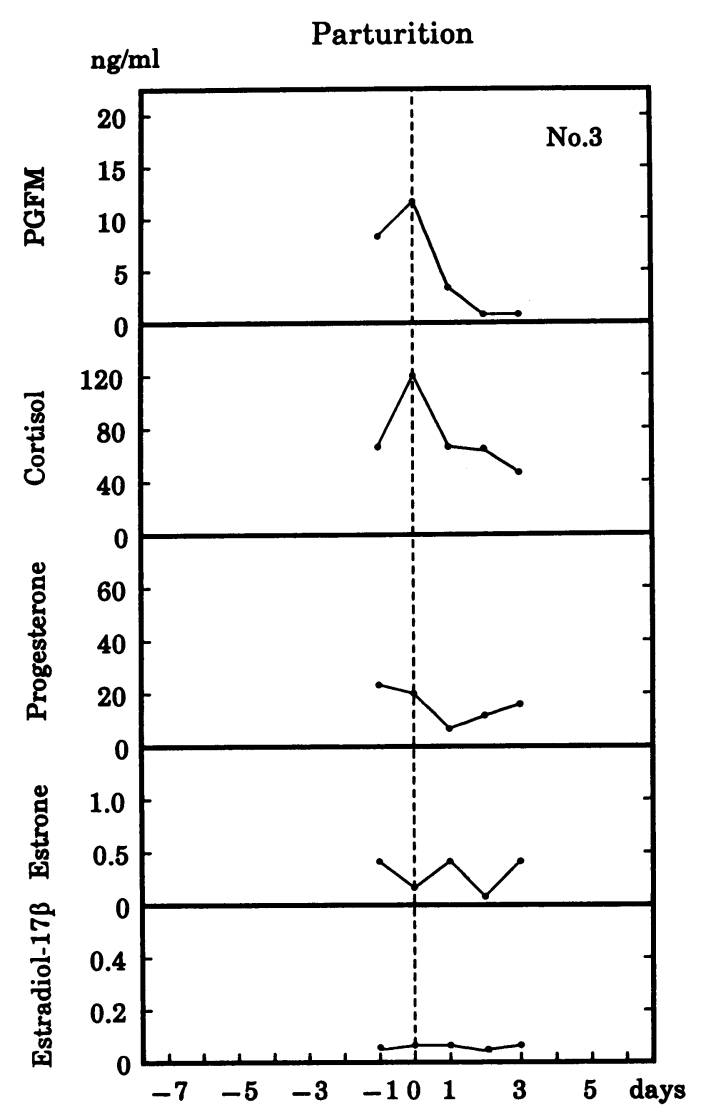

Fig. 3. Changes of PGFM, Cortisol, Progesterone, Estrone and Estradiol-17 $\beta$ in blood of horse No. 3 pre- during and postparturition.

$6)$.

On prePD 2, the cortisol concentration showed gradual increases and quickly attained the peak level on parturition. However, this hormone declined suddenly on postPD 1 to eventually reach the prePD level (Fig. 6).

Progesterone was high on prePD 2, but declined to $20.5 \pm 3.8 \mathrm{ng} / \mathrm{ml}$ on parturition. This was followed by further decreases to register at $4.3 \pm 1.6$ $\mathrm{ng} / \mathrm{ml}$ on postPD 1 (Fig. 6).

Estrone already showed a declining trend at the start of the experiments. The readings indicated a high value of $0.69 \pm 0.24 \mathrm{ng} / \mathrm{ml}$ on prePD 2, declined to $0.45 \pm 0.14 \mathrm{ng} / \mathrm{ml}$ on prePD 1 and dropped to $0.37 \pm 0.10 \mathrm{ng} / \mathrm{ml}$ on parturition. The level low thereafter.

Estradiol- $17 \beta$ varied around $0.15 \mathrm{ng} / \mathrm{ml}$ until prePD 1 , decreased on parturition and decreased to $56.9 \pm 32.4 \mathrm{pg} / \mathrm{ml}$ on postPD 1 ( $1 / 3$ of $\mathrm{prePD}$ level). However, the level dropped thereafter (Fig. $6)$. A comparison of estrone with estradiol-17 $\beta$,

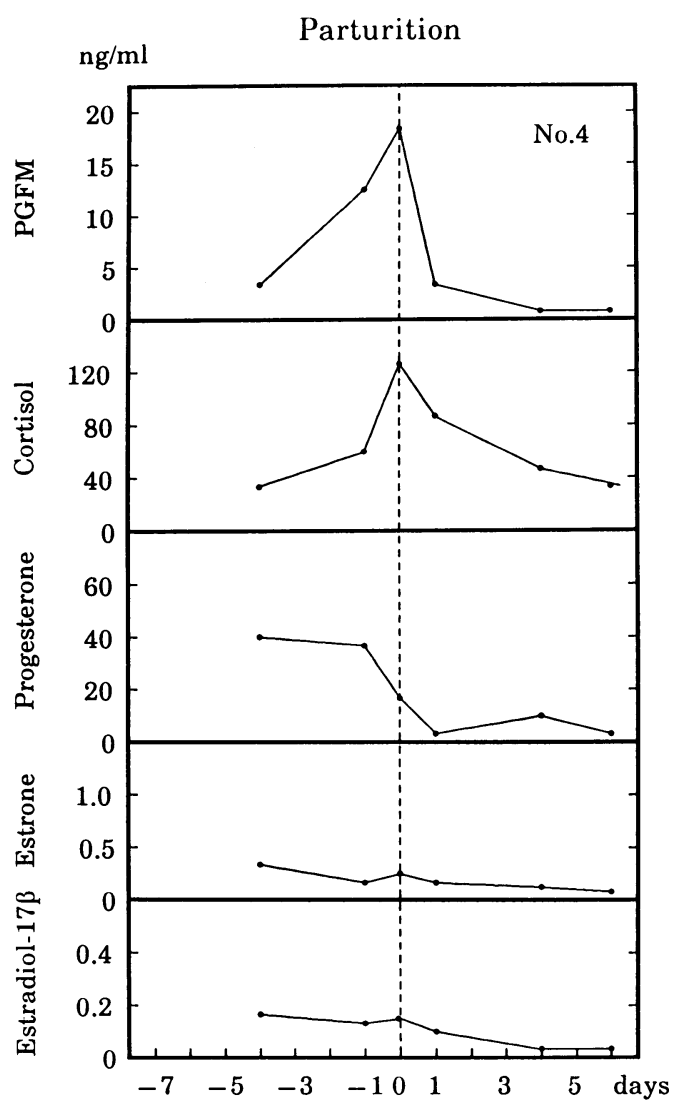

Fig. 4. Changes of PGFM, Cortisol, Progesterone, Estrone and Estradiol- $17 \beta$ in blood of horse No. 4 pre- during and postparturition.

showed the former approximately 3 to 5 times as high as the latter on the whole.

\section{Discussion}

Liggins et al. [7] experimented extensively on the mechanism of parturition in sheep extensively. The important role played by the adrenal cortex in parturition induction has been demonstrated. During pregnancy, endogeneous secretory functions of the hypothalamus-hypophysis-adrenal axis are enhanced, and a large quantity of cortisol is released from the adrenal cortex. Cortisol acts on the embryo placenta, enhances estrogen secretion and inhibits progesterone release. In addition, estrogen acts on the mother's placenta to trigger $\mathrm{PGF}_{2} \alpha$ biosynthesis. Biosynthesized $\mathrm{PGF}_{2} \alpha$ in the placenta is transported to uterine muscles and transits swiftly into the uterine venous bloodstream. 


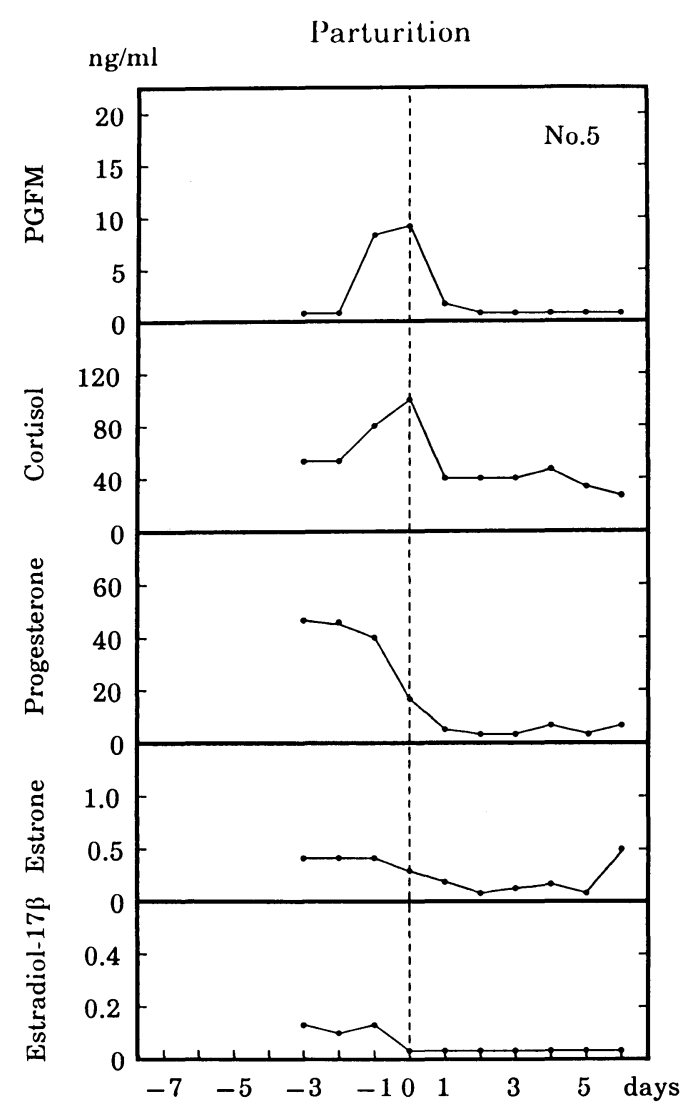

Fig. 5. Changes of PGFM, Cortisol, Progesterone, Estrone and Estradiol-17 $\beta$ in blood of horse No. 5 pre- during and postparturition.

When PGFM concentrations in the uterine venous blood were investigated $30 \mathrm{~min}$ preparturition, during parturition and $30 \mathrm{~min}$ postparturition, Lovell et al. [3] found them to increase suddenly on parturition. In our experiments, PGFM showed a sudden increase on prePD 1 and registered the peak on parturition, suggesting a close relationship between PGFM and parturition. PGFM in the blood increased prior to that of cortisol pre-parturition and its post-parturition decreased was delayed slightly, suggesting that PGFM induces cortisol release in certain ways not yet explained.

In parturition induction in horses by $\mathrm{PG}$, with the use of a single sc bolus administration of 12.5 or $2.5 \mathrm{mg} \mathrm{PGF}_{2} \alpha$ to 40 - to 150 -day pregnant ponies, resulted in about half of them having miscarriages 3-9 days after treatment, regardless of the pregnancy term [8]. Moreover, in ponies of 80 - to 300-day pregnancy term, repeated single bolus sc administrations of $2.5 \mathrm{mg} \mathrm{PGF}_{2} \alpha$ on a

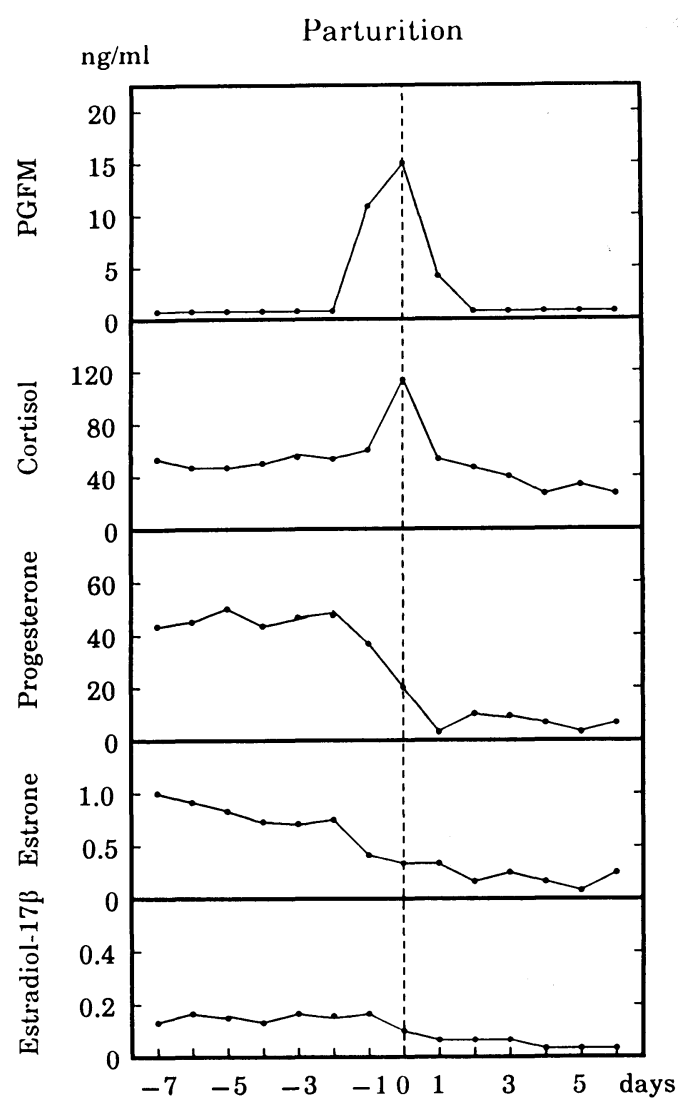

Fig. 6. Changes of PGFM, Cortisol, Progesterone, Estrone and Estradiol-17 $\beta$ in blood of horse pre-during and postparturition.

continuous basis at 12-h intervals induce miscarriages at a mean of $38.0 \mathrm{~h}$ after the first treatment for a mean of 3.7 administrations in all animals. As such, $\mathrm{PGF}_{2} \alpha$ is applicable in parturition induction in horses, and is known to be related to parturition induction in horses.

Progesterone in the blood determined in the present study registered a high value of more than $40 \mathrm{ng} / \mathrm{ml}$ on prePD 7 , and was further increased at 11-month pregnancy term. Progesterone began to decrease on prePD 1 to record half the peak value on parturition and dropped sharply on postPD 1 .

Estrone in the jugular venous blood around parturition in thoroughbred mares registered a high value of 35 times the level of estradiol- $17 \beta$, but declined on parturition. Moreover, estradiol$17 \beta$ showed a decreasing tendency on parturition initiation. Apart from the hitherto unpublished estrone concentrations, the estradiol-17 $\beta$ changes coincided well with those reported previously [9].

Cortisol concentrations in rabbits [10], cows [11] 
and pigs [12] have been documented to increase on parturition. Lovell et al. [3] have reported no changes in $11 \beta$-hydroxycorticosteroids from prePD 45 to postPD 15 in horses. However, corticosteroid has been observed to register a significant increase from $12 \mathrm{hrs}$ prior to parturition [13]. In our present study, sharp corticosteroid increases were recorded from prePD 1 to the time of parturition, confirming previous findings [13]. Moreover, successful parturitions were induced with repeated administrations with $100 \mathrm{mg}$ dexamethasone in pregnant mares from pregnancy day 321 to $324[14,15]$. As such, corticosteroid hormones are probably the factors that influence parturition.

\section{Acknowledgments}

The authors wish to thank Dr. Anthony Foong for reading the manuscript.

\section{References}

1. Holtan DW, Nett TM, Estergreen VL. Plasma progesterone in pregnant, postpartum and cycling mares. J Anim Sci 1975; 40: 251-260.

2. Kindahl H, Kundsen O, Madej A, Edqvist LE. Progesterone, prostaglandin $\mathrm{F}_{2} \alpha$, PMSG and oestrone sulphate during early pregnancy in the mare. J Reprod Fert 1982; 32 (Suppl): 353-359.

3. Lovell JD, Stabenfeldt GH, Hughes JP, Evans JW. Endocrine patterns of the mare at term. $J$ Reprod Fert 1975; 23 (Suppl): 449-456.

4. Makino T. Radioimmunoassay of plasma sex steroids. Folia Endocr Jpn 1973; 49: 629-645 (in Japanese).

5. Den $\mathbf{N}$, Kamisato $\mathbf{T}$, Takasaki $\mathbf{T}$, Haruyama $\mathbf{N}$, Yoshida T, Takagi S, Kokubu T, Kanbegawa A. Measurement of pregnenolone, $17 \alpha$-hydroxypregnenolone and dehydroepiandrosterone. Hormone and Clinic 1978; 26: 309-314 (in Japanese).

6. Satoh K, Yasumizu T, Fukuoka $\mathbf{H}$, Kinoshita $\mathbf{K}$, Kaneko Y, Tsuchiya M, Sakamoto S. Prostaglan$\operatorname{din} \mathrm{F}_{2} \alpha$ metabolite levels in plasma, amniotic fluid, and urine during pregnancy and labor. Am J Obstet Gynecol 1979; 133: 886-890.

7. Liggins GC, Fairclough RJ, Grieves SA, Kendall JZ, Knox BS. The mechanism of initiation of parturition in the ewe. Rec Prog Horm Res 1973; 29: 111-150.
8. Douglas RH, Squires EL, Ginther OJ. Induction of abortion in mares with prostaglandin $\mathrm{F}_{2} \alpha . J$ Anim Sci 1974; 39: 404-407.

9. Noden PA, Oxender WD, Hafs HD. Plasma luteinizing hormone, progesterones and estrogens in mares during gestation, parturition and first postpartum estrus (foal estrus). Am J Vet Res 1978; 39: 1964-1967.

10. Baldwin DM, George HS. Plasma levels of progesterone, cortisol and corticosterone in the pregnant rabbit. Biol Report 1974; 10: 495-501.

11. Adams WM, Wadner WC. The role of corticoid in parturition. Biol Report 1970; 3: 223-228.

12. First NL, Bosc MJ. Proposed mechanisms controlling parturition and the induction of parturition in swine. J Anim Sci 1979; 48: 1407-1421.

13. Barnes RJ, Nathanielsz PW. Plasma progesterone and oestrogens in fetus and mather in late pregnancy. J Reprod Fert 1975; 23 (Suppl): 617-623.

14. Carol CA, Sullivan JJ, First NL. Induce of premature parturition by parenteral administration of dexamethasone in the mares. JAVMA 1974; 165: 721-722.

15. First NL, Carol CA. Dexamethasone-induce Parturition in pony mares. J Anim Sci 1977; 44: 1072-1075. 